\title{
A Comparative Study on Public- Private Partnership (PPP) for Creating Highly Skilled and Productive Business Graduate in Bangladesh
}

\author{
Mohammad Yunus
}

Associate Professor \& Coordinator, Department of Business Administration, International Islamic University Chittagong. Bangladesh

\begin{abstract}
Public Private Partnership (PPP) is a recent phenomenon in Bangladesh to upgrade quality education and create potential managerial manpower for smooth and sustainable economic development of this county which although, highly overpopulated, but lack skilled and worthwhile \& effective managerial manpower. The course curriculum of both public and private universities especially BBA and MBA programs should be well designed and well patterned to satisfy needs of the county. The faculty of Business Administration of a Private university i.e BGC Trust University Chittagong and Faculty of Business Administration (FBA) of a public university, i.e University of Chittagong (CU), are trying to upgrade and improve syllabuses of both BBA and MBA in line with local North South University (Private University market leader) and other universities of North America, South East Asia and India. The rules, regulation, enactments etc must be made logical and attractive to fit accountability of teachers and others concerned. Training and development Programs must be befitting to enhance skills of teachers $\mathcal{E}$ other related human resources.
\end{abstract}

Key words: Public-Private Partnership, Private University, Public University, Programs JEL Classification Code: E31

\section{INTRODUCTION}

$\mathrm{P}$ ublic Public Private Partnership (PPP) is considered as a cooperative venture between public and private sectors because it is built on the expertise of each partner that best meets the clearly defined public needs through appropriate allocation of resources, risks and rewards (Canadian council for PPP: 1998). PPPs are geared toward improvement of existing services provided by both sectors with an emphasis directed on system efficiency, effectiveness, quality, equity and accountability (Wang: 1999). PPP's aim is to promote improvements in the financing and provision of services both from the public and from the private sectors, but not to increase the role of one over the other.. PPP also offers value for money, radical opportunity to return for modernization, reduced cost over the whole life of a project, improved transparency of costs, gains from innovation, service improvements, better allocation of risks and a better chance of delivering projects on time and on budget. Further, PPP may offer new focus of accountability and a degree of democratic potential (Mayo and Moove 2001). Thus, PPP refers to an outcome focusing long term formal contractual partnership between public and private agencies on the basis of shared revenue-riskreward-responsibility approach.

Everyday business trends are becoming more unconventional and unusual due to accelerated paces in technological changes, management practices and cultural diversities. So, business education is the only weapon an organization can depend on for success. Unfortunately, business education in South Asia is still at an infant stage. This situation is more intense in Bangladesh, in particular. Avery little emphasis has been given to promote this business education in Bangladesh since independence. It is now widely admitted that, if this country is to benefit from the emerging globalized economy and pro-market policies, it must professionalize its business education and improve the existing business management programs and facilities. Further, globalization and liberalization policies of world economy opened up new business opportunities in different levels of markets. As a result, there is a growing demand of productive business graduates in successive years in the world in general and in Bangladesh in particular.

The review of the early works in the same subject in Bangladesh revealed that quality enhancement through PPP as a whole or various aspects of quality enhancement in higher education in context of business education were not examined in detail through research project. This research gap induced the author to undertake this study on "A Comparative Study on Public- Private- Partnership (PPP) for Creating Highly Skilled and Productive Business Graduates in Bangladesh".

\section{ObJectives}

The main objective of this study is to highlight the role and potential of PPP in education for creating 
highly skilled business graduates for meeting the need of globalization, knowledge economy, job market both at home and abroad and higher productivity, better economic growth in Bangladesh. The specific objectives of this study are as follows:

- To analyze the role, framework of PPP and identify the available existing services for higher education quality enhancement.

- To identify the training needs and analyze the framework of PPP for training of higher education institution actors.

- To find out the relevance of curricula to meet the market demand and analyze the framework of PPP for curriculum update.

- To analyze the framework of PPP for modernization of business teaching methodology and explain the nature of PPP between FBA (C.U) and FBA( BGC Trust) for maximum utilization of expertise of each university.

- To study post learning utilization, analyze research findings and suggest some policy strategies for the improvement of existing education services of both universities with an emphasis on system efficiency, effectiveness, quality, equity and accountability.

\section{Methodology}

Both primary and secondary data have been used in the present research work. Primary data have been collected from sample responded through pre -tested questionnaire prepared in the light of the objective of the study. The size of sample respondents consists of $2(1+1)$ Vice Chancellors, $2(1+1)$ Deans, $20(10+10)$ teachers, 20 $(10+10)$ officials , $10(5+5)$ policymakers, $10(5+5)$ staffs and $100(50+50)$ Students

Both quantitative and qualitative research instruments have been used in the study. Participant observations, group discussions, focus group study, in-depth interview and workshops have been used to collect qualitative data for research purpose. Attitudes of the sample students have been evaluated through Likert type five points scale. In order to present the fact in logical format, the supporting and relevant secondary data have been collected through desk research. The desk study has covered research works, conference proceedings, World Bank reports, and policies of Ministry of Education, text books, internet, website and the like. The collected data have been analyzed and processed with care in order to make the study more informative and useful to the policymakers and other stakeholders.

\section{Methodology Matrix}

\begin{tabular}{|c|c|c|c|c|}
\hline Objectives & Indicators & Data Needed & Data sources & $\begin{array}{c}\text { Methods of data } \\
\text { collection }\end{array}$ \\
\hline 1 & $\begin{array}{l}\text { *Attendance Result } \\
\text { * Co-curricular activities } \\
\text { * Teacher's qualification } \\
\text { * Curriculum structure } \\
\text { * Curriculum contents } \\
\text { * Teacher student ratio } \\
\text { * Educational program } \\
\text { * Teaching methods } \\
\text { * Curriculum structure } \\
\text { * Teaching aid } \\
\text { * Teacher's qualification } \\
\text { * Staff's qualification }\end{array}$ & $\begin{array}{l}\text { *Student's attendance } \\
\text { * Student's result's } \\
\text { * Student's participation in } \\
\text { co-curricular activities } \\
\text { * Teacher student ratio } \\
\text { * Curriculum content } \\
\text { * Teaching aid } \\
\text { *Teacher's qualification } \\
\text { * Program } \\
\text { * Syllabus } \\
\text { * Teacher- student interaction } \\
\text { * Course combination } \\
\text { * Teacher-student contact hour } \\
\text { * Staff's work load } \\
\text { * Staffs support } \\
\text { * Availability of teaching aid }\end{array}$ & $\begin{array}{l}\text { * Institution's } \\
\text { records } \\
\text { * Documents } \\
\text { * Inventory } \\
\text { * Official } \\
\text { documents } \\
\text { * Teacher } \\
\text { * Student } \\
\text { * Staff }\end{array}$ & $\begin{array}{l}\text { * Survey method } \\
\text { * Peer interview } \\
\text { * Survey method } \\
\text { * Observation } \\
\text { method } \\
\text { * Interview } \\
\text { method }\end{array}$ \\
\hline 2 & $\begin{array}{l}\text { * Scholarship } \\
\text { * Fellowship } \\
\text { * Research grant } \\
\text { * Nomination } \\
\text { * Participation } \\
\text { * Faculty exchange } \\
\text { * Interdisciplinary project }\end{array}$ & $\begin{array}{l}\text { * Completion of training } \\
\text { * Completion of degree } \\
\text { * Completion of research } \\
\text { work } \\
\text { * Faculty data } \\
\text { * Program data } \\
\text { * Institutional data }\end{array}$ & $\begin{array}{l}{ }^{*} \text { Official } \\
\text { document } \\
{ }^{*} \text { Faculty } \\
\text { * Program } \\
{ }^{*} \text { Institution }\end{array}$ & $\begin{array}{l}\text { * Survey method } \\
\text { * Survey method }\end{array}$ \\
\hline 3 & $\begin{array}{l}\text { * Course design } \\
\text { * Technological content } \\
\text { * Structure of curriculum } \\
\text { * Contents of curriculum }\end{array}$ & $\begin{array}{l}\text { * No. of applicant seeking } \\
\text { admission } \\
\text { * No. of seats available } \\
\text { * Nature of courses } \\
\text { * Technical courses } \\
\text { * Market demand }\end{array}$ & $\begin{array}{l}{ }^{*} \text { Official } \\
\text { document } \\
{ }^{*} \text { Trained faculty } \\
{ }^{*} \text { Leading } \\
\text { professionals }\end{array}$ & $\begin{array}{l}\text { * Survey method } \\
\text { * Peer interview } \\
\text { * Depth interview }\end{array}$ \\
\hline 4 & $\begin{array}{l}\text { * Application of IT } \\
\text { * Faculty exchange } \\
\text { * Student's participation }\end{array}$ & $\begin{array}{l}\text { * Software Programming } \\
\text { * Participant's information }\end{array}$ & $\begin{array}{l}{ }^{*} \text { IT expert } \\
* \text { Prospective } \\
\text { participant } \\
\end{array}$ & $\begin{array}{l}\text { * Peer interview } \\
\text { * Interview }\end{array}$ \\
\hline
\end{tabular}


Asian Business Review, Volume 3, Number 1/2013 (Issue 5)

ISSN 2304-2613 (Print); ISSN 2305-8730 (Online)

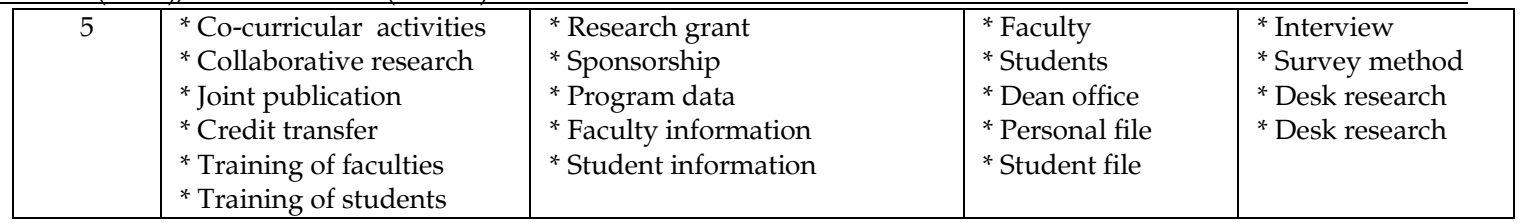

\section{Key Findings AND Discussions ON KEY FINDINGS}

The study highlighted the sample private university run by the part-time teachers of the public university. It is evident that the academic program of sample public university is suffering due to involvement of teachers of public university in the academic program of private university. It appears that the model of the Public Private Partnership (PPP) may be advocated for better academic management of both sample universities. Thus, the junior teachers of sample private university will get opportunity to learn from the teachers of sample public university. As such, the junior teachers will be trained by learning through interaction with teachers of public university. Further, the ratio of professor and lecturer in sample private university is 1:24. It is also interesting that there is no full-time associate professor in the sample private university. (Table- 1 in appendix).

Again, the academic program of private university has been hampered due to the lack of skilled, experienced and talented teachers. Moreover, the internationally standard set-up of Professor, Associate Professor, Assistant Professor and Lecturer is 1:2:4:8.

Table-2 in appendix depicts that the ratio of Ph.D holder teachers in sample public and private universities are $29.1 \%$ and $22.2 \%$ respectively. But the international standard of Ph.D holder teacher at university level is $40 \%$ of total teachers. The survey data evidence that both sample public and private universities consequently adversely affecting the quality education in sample universities. The second degree holder teachers of sample public and private universities are $28 \%$ and $6.67 \%$ respectively. It has been further identified that without second degree holder teachers are $41.8 \%$ and $71.1 \%$ respectively in sample Public and Private Universities. This is alarming for quality assurance as well as quality enhancement of the higher education in Bangladesh. It seems that training is a must for the teachers of the universities either in public or private sector.

In the sample public university, there is a committee of courses for reviewing the syllabus of the department yearly. In this committee, there are three external senior faculty members of three universities are involved for quality control in the preparation and review of the curriculum of the departments. Again, one third of the faculty members of the department based on seniority will be involved in the review and inclusion of new courses in the curriculum for meeting the need of market demand, knowledge economy and revolution of information technology of the world. The proposed curriculum and syllabus will be reviewed in the faculty meeting of the public university. Finally, the syllabus and curriculum will be approved in the 'Academic Council' of the sample pubic university. But, it has been reported that the curriculum and syllabus of sample Private University has been approved by the University Grants Commission (UGC), Dhaka. It has been learnt that expert opinions have been taken by the UGC on syllabus and curriculum of the concerned private university. In the light of the suggestions of experts on syllabus and curriculum, necessary corrections, modifications and improvements have been made by the sample private university, and this revised syllabus and curriculum have been submitted to the UGC for the final approval of the curriculum. The UGC, then, sent the revised copy of syllabus and curriculum to the concerned experts for verification, confirmation and finalization of the curriculum and syllabus of the 'Faculty of Business Administration' of sample Private University.

It appears that curriculum and syllabus will be revised and updated periodically to meet the requirements of job market at home and abroad, knowledge economy and creating competitive human resources to meet the requirement of globalization and liberalization of world economy.

The training of institutional actors may open opportunities to enrich the teaching skills of junior faculty; and senior faculty will participate in seminars and organize workshop to update business curricula and to share experiences, skills, knowledge in teaching methods with corporate managers in order to build up valid teaching methodology in sample universities. The junior teachers of both universities will interact with senior teachers of sample universities for developing common idea of thinking, identifying potential research areas for higher studies like M.Phil, Ph.D. and focusing common action of agenda for further collaboration and cooperation through PPP among the institutional actors of the sample universities. Further, the teachers of sample universities can interact with each other for prioritizing their research agenda, identifying areas of research interest through mutuality model for sharing of ideas, experiences and learning by win-win strategy.

Faculty development is a continuous process of improvement for meeting the requirements of quality education in higher studies. These methods are (i) learning by performing (ii) mentoring (iii) workshops (v) 
seminars (vi) case studies (vii) role playing (viii) simulations (ix) problem-solving etc.

The respondents significantly differ in their responses to the statement regarding application of prescribe curriculum in their respective business education program. In the case of 58\% respondents of public university believed that prescribed curriculum is essential for quality business education where-as only $27 \%$ respondents of private university agreed the statement. It appears that content and structure of the curriculum may be updated to meet the requirement of clientele services. Table-3 It reveals that $41 \%$ respondents of the public university favor of updated curriculum in every year, followed by $3 \%$ in every two years and rest $22 \%$ in more than two years. The same sort of data have been collected from that sample Private University. It portrays that $40 \%$, $31 \%$ and $29 \%$ respondents are in favor of every two years, more than two years and in every one year respectively. Research evidences that out of 50 sample students of public university interviewed, $20 \%$ or $40 \%$ opined in favor of lectures by teachers as a teaching method. It is apparent from the table that $36 \%, 25 \%, 20 \%$ of the students of sample public university opined in favor of group discussion and presentation, case study, individual presentation and assignment respectively. Table- 4 reveals that out of 50 sample students of sample the private university interviewed, 20 or $40 \%$ opined in favor of group discussion as a teaching method. The table, further, evidences that $30 \%, 25 \%, 20 \%$ and $17 \%$ of the sample students of sample private university opined in favor of assignment, individual presentation, case study and lecture method respectively. The sample students of public university rated lectures method as the best teaching method. Their arguments in favor of lecture method are (i) it is time saving method; (ii) students listen lecture attentively; (iii) teachers provide the knowledge related to the subject; (iv) students can interact with teachers; ( $v$ ) students can prepare notes based on deliveration of the lectures of the teachers. In the case of sample students of private university, group discussion was rated as the best teaching method. The arguments in favour of group discussion are (i) it involves more participation of students in learning process; (ii) it develops creativity among students; (iii) participatory method opens more learning opportunities for the students. It appears that other teaching methods are brainstorming, conference, role play, workshop, seminars and so on. This student's perception and rating about business teaching methods is a way of suggesting improvements in teaching as well as in learning process for preparing productive business graduates to meet the expectations of knowledge economy and job market demand at home and abroad.

\section{Competition in Education Market}

In education market, there are two actors playing significant role to attract students, teachers and supportive staffs for their concerned institutions. These

\section{POLICY IMPLications}

Rules, regulations, policies and performance indicators are set in a way so that appropriate levels of accountability may be ensured in the processes of PPP between sample universities. Thus, the procedure may be free of corruption and may ensure the integrity between the public and private university taking effective measures in different stages of organization, operation and management of PPPs.

\section{PROMOTING PPP}

High standards of corporate governance, transparency, rule of law including protection of property and contractual rights will be established and maintained in order to ensure successful operation of PPP in the concerned universities.

\section{Quality Assurance and Incentives}

Enabling regulatory environment, providing clear and streamlined registration processes, setting up effective quality assurance system and providing incentives for partners may ensure the efficient and effective operation of successful PPP in the sample universities.

\section{Competitive Fairness}

The process of awarding PPP contracts may be competitive and rewarding. The whole mechanism will be characterized by fairness, transparency and nondiscrimination.

\section{Good Faith}

Private University may observe the principles and standards for responsible business conducts that have been agreed on with the public university and that will participate in such projects in good faith. Both partners may work on the basis of agreed principles and rules of game for better management of PPP.

\section{Risk Sharing}

PPP contracts can achieve an increased level of risksharing between the public and private universities. This risk-sharing strategy is likely to increase efficiency and effectiveness in the delivery of education services in both sectors i.e. government and private.

\section{Matching Supply and Demand}

In practice, the sample public university has less autonomy in hiring teachers in different levels of education structure due to government's regulatory mechanism and influence of ruling party of the country. Research indicates that the private sector fails to attract experienced and talented teachers for the university. In the social status, the teachers of public university enjoy higher dignity, honor, and recognition and so on. To overcome this paradox, PPP can be a strategy between the supply of and demand for quality education in general and business education in particular.

components are (i) Public universities (ii) Private universities. The new element in education industry will emerge as Universities in Public-Private-Partnerships. Thus, the three types of universities may create perfect 
competition in the education sector by providing facilities, rewards and incentives to the teachers, students, supportive staffs and other stakeholders. The PPP may open up new opportunities both for public and private universities.

\section{Concluding Observation}

In a country like Bangladesh, there is no existence of any university operating PPP Model. Like public and private universities, a new act may be enacted for starting universities in PPP model. The government may create an enabling framework that includes (i) defining the partners in the national education strategy for starting universities in PPP (ii) setting clear objectives, procedures and criteria that the partners must meet to operate universities in PPP model. (iii) introducing fund management system that integrate public and private universities based on criteria e.g. responsive, targeted and impartiality (iv) establishing an effective quality assurance and quality enhancement system for creating productive graduates. Further, there are several different aspects to a policy framework that encourage the growth of universities on PPP model in Bangladesh. These include quality indicators that will encourage improvements in the performance of both public and private universities. They must follow operating requirements; performance standards meet performance benchmarks, reward innovation and quality improvements by creating universities on PPP model in Bangladesh.

\section{REFERENCES}

Mayo, and Moove, H. (2001), The Mutual State: How Local Communities can run Public Services: London: New Economic Foundation.

The Canadian Council for PPPs (1998), Retrieved November 30, 2001 from http://home:inforamp.nef/partner/awardfaq.htm

Wang, yidan (1999), Public-Private-Partnerships in Health and Education: Conceptual issues and options, paper prepared for Manila Social policy Forum: The New Social Agenda for East, Southeast and Central Asia, Joint ADB-World Bank Conference,9-12 November, pp 6-7. 